Article

\title{
Soil Respiration Dynamics in Bromus erectus-Dominated Grasslands under Different Management Intensities
}

\author{
Matteo Francioni ${ }^{1}{ }^{\circledR}$, Laura Trozzo ${ }^{1}$, Marco Toderi ${ }^{1}{ }^{\circledR}$, Nora Baldoni ${ }^{1}$, Marina Allegrezza ${ }^{1}$, \\ Giulio Tesei ${ }^{1}$, Ayaka Wenhong Kishimoto-Mo ${ }^{2}$, Lucia Foresi ${ }^{3}$, Rodolfo Santilocchi ${ }^{1}$ \\ and Paride D'Ottavio ${ }^{1, *(D)}$ \\ 1 Dipartimento di Science Agrarie, Alimentari ed Ambientali, Università Politecnica delle Marche, \\ 60131 Ancona, Italy; m.francioni@staff.univpm.it (M.F.); 1.trozzo@pm.univpm.it (L.T.); \\ m.toderi@univpm.it (M.T.); n.baldoni@pm.univpm.it (N.B.); m.allegrezza@univpm.it (M.A.); \\ g.tesei@pm.univpm.it (G.T.); r.santilocchi@univpm.it (R.S.) \\ 2 National Institute for Agro-Environmental Sciences, Tsukuba 305-8604, Japan; mow@affrc.go.jp \\ 3 East Malling Research, East Malling ME19 6BJ, UK; lucia.foresi@emr.ac.uk \\ * Correspondence: p.dottavio@univpm.it; Tel.: +39-071-2204156
}

Received: 3 December 2019; Accepted: 26 December 2019; Published: 30 December 2019

\begin{abstract}
Reduction of soil greenhouse gas emissions is crucial to control increases in atmospheric $\mathrm{CO}_{2}$ concentrations. Permanent grasslands are of considerable importance in climate change mitigation strategies as they cover about $13 \%$ of the global agricultural area. However, uncertainties remain for the effects of management practices on soil respiration, especially over the short term. This study investigated the influence of different mowing intensities on soil respiration over the short term for Bromus erectus-dominated grasslands in the central Apennines. From 2016 to 2018, soil respiration, temperature, and moisture were measured under three different management systems: customary management, intensive use, and abandonment. Both soil water content and temperature changed over time, however mowing did not affect soil water content while occasionally altered soil temperature. The intensive use promoted higher seasonal mean soil respiration compared to the abandonment only during the 2016 growing season. Soil temperature was the main driver of soil respiration above a soil water content threshold that varied little among treatments (18.23-22.71\%). Below the thresholds, soil moisture was the main driver of soil respiration. These data suggest that different mowing regimes have little influence on soil respiration over the short term in Bromus erectus-dominated grasslands. Thus, more intensive use would not have significative impacts on soil respiration, at least over the short term. Future studies need to clarify the role of root mycorrhizal and microbial respiration in the light of climate change, considering the seasonal redistribution of the rainfall.
\end{abstract}

Keywords: carbon cycle; $\mathrm{CO}_{2}$; greenhouse gases; mowing; Natura 2000; permanent grassland; semi-natural dry grasslands

\section{Introduction}

According to the fifth assessment report of the Intergovernmental Panel on Climate Change, annual greenhouse gas (GHG) emissions from agricultural production in 2000-2010 were estimated at 5.0-5.8 Gt CO 2 eq. $\mathrm{yr}^{-1}$ while annual GHG flux from land use and land-use change activities accounted for approximately 4.3-5.5 $\mathrm{Gt} \mathrm{CO}_{2}$ eq. $\mathrm{yr}^{-1}$ [1]. The same report estimated that over recent decades, the cumulative $\mathrm{CO}_{2}$ emissions from agricultural land uses (i.e., croplands, forest lands, and grasslands) have increased by about $40 \%$. 
The $\mathrm{CO}_{2}$ efflux released into the atmosphere by the biological activities of plant roots, soil microbes and animals is defined as soil respiration [2], and this represents the second-largest carbon flux between the terrestrial ecosystem and the atmosphere on a global scale [3]. As well as global warming, which might have positive feedback on soil $\mathrm{CO}_{2}$ release from the soil carbon pool [4], human activities have crucial roles in soil carbon cycling, in terms of land-use changes and agricultural practices $[5,6]$.

To face this issue, there is a need to adopt mitigation strategies to preserve the carbon pools of terrestrial ecosystems $[5,7,8]$. In particular, the soil carbon pool of the first soil layers is one of the main abiotic factors affecting soil respiration [9], thus mitigation strategies must include the best practices that address the soil (e.g., tillage, amendments application, land-use change), the crops (e.g., nutrients, residues, water management), and the livestock (e.g., feeding, manure management, stocking densities) to reduce GHG from agricultural systems [1].

Permanent grasslands might indeed be important for climate change mitigation strategies as they cover about $13 \%$ of the global agricultural area [10], which represents more than a third of the European agricultural area [11]. Projected scenarios have suggested that grasslands may face major issues due to temperature and atmospheric $\mathrm{CO}_{2}$ concentration increase as well as changes in precipitation patterns [5]. The latter appears to be particularly relevant in areas with low summer rainfall (i.e., southern Europe) because precipitation after prolonged dry periods can enhance $\mathrm{CO}_{2}$ efflux from the soil to the atmosphere $[12,13]$.

Bromus erectus-dominated grasslands are semi-natural communities of secondary origin that are included in the list of habitats of European Community interest: Habitat code $6210\left({ }^{*}\right)$ "Semi-natural dry grasslands and scrubland facies on calcareous substrates (Festuco-Brometalia) (*important orchid sites)" (EU Habitats Directive 92/42/EEC, Annex I). These are also among the most prevalent grasslands, with about 600,000 ha in the EU Natura 2000 network, with the largest areas reported for Italy (33\%) and Romania (25\%). Natura 2000 is a network of nature protection areas (both terrestrial and marine) in the territory of the European Union. It is made up of Special Protection Areas (SPA) and Special Areas of Conservation (SAC) designated under the Birds Directive (EU Birds Directive 79/409/EEC replaced by Directive 2009/147/EC) and Habitats Directive (EU Habitats Directive 92/42/EEC), respectively.

High levels of animal and plant biodiversity are linked to permanent grasslands [14,15], which in turn provide a large number of ecosystem services $[10,16]$. These include supporting services (e.g., primary production, nutrient cycling), cultural services (e.g., landscape aesthetic value, recreational experiences), provisioning services (e.g., food and forage production), and regulating services (e.g., carbon sequestration, erosion control) [17]. Secondary grasslands include numerous plant communities whose characteristics vary in relation to the environmental conditions and, in relation to their potential production, they are subject to different management intensities [18].

Many studies on permanent grasslands have focused on the effects of management practices on forage yield and herbage quality (e.g., [19]) and/or on plant diversity (e.g., [20,21]), but little is known about soil respiration compared to other ecosystems (e.g., forests) [22]. The need to further investigate their role in GHG mitigation strategies is highlighted by the few inconsistent data about the effect of management practices (e.g., grazing and/or mowing intensity) on soil respiration and its drivers [23]. Indeed, many papers reported contrasting results on the effect of management practices that involve herbage removal on soil temperature and/ or water content, which are among the main drivers of soil respiration. For example, herbage removal might increase soil temperature [24], but the tall-grass cover might cause a shading effect and thus decrease it [25]. In many case-studies mowing had no effect on soil moisture (e.g., [24,26]), while in some other cases the opposite effect is reported (e.g., [25,27]).

Results on the effect of management practices on soil respiration and its drivers appear even more uncertain when the time-scale is also considered. For example, it has been reported that over the medium to long term, heavy grazing on permanent grasslands might alter the soil respiration by alterations to the soil microbial communities, while light grazing has more limited effects [23]. A recent study on permanent grasslands reported that a land-use change from permanent grasslands to arable lands does not influence the microbial soil respiration in mountain areas, while the soil carbon stock 
can be halved over a few decades due to soil tillage and erosion [28]. Switching from the long-term to the short-term perspective (1-3 years), some studies have reported that mowing results in reduction of soil respiration $[24,25]$, while other studies have reported that soil respiration of permanent grasslands might not be influenced by mowing [26]. A 2 year experiment in a Mediterranean grassland showed that defoliation reduced the carbohydrates translocated to the roots affecting/reducing both microbial and root-derived $\mathrm{CO}_{2}$ effluxes [29]. In contrast, a short-term experiment (8-14 days) carried out in temperate mountain grasslands reported a soil respiration decrease due to a reduction in microbial activity (e.g., [30]). At the same time, root respiration was affected to a lesser extent since it was supported by carbohydrates present in the reserve organs. Thus, management practices appear to have significant effects on soil respiration even over the short-term, although on a basis that tends to be context-dependent.

To date, many studies have investigated the effect of management practices on soil respiration of dry or semi-dry grasslands (e.g., [24,26,31,32]), very few on Bromus spp.-dominated grasslands (e.g., [25]), and to the best of our knowledge, no one has reported data on the effect of management practices on soil respiration for Bromus erectus-dominated grasslands, despite covering large areas, being of the greatest conservational importance $[10,16]$, and being largely used in large scale grazing systems [33].

In line with this perspective, the present study was designed to investigate the effects of different management intensities, in terms of mowing regimes applied for three consecutive years, on soil respiration, soil temperature, and soil moisture (i.e., dynamics and seasonal mean values) for a permanent mountain Bromus erectus-dominated grassland of the central Apennines.

\section{Materials and Methods}

\subsection{Study Area}

The study area is located in the territory of Monte San Vicino (central Apennines, Marche Region, Italy) and within the Natura 2000 SPA IT5330025- "Monte San Vicino e Monte Canfaito", which includes two SAC (IT5330015-“Monte San Vicino"; IT5320012_“"Valle Vite-Valle dell'Acquarella") and two main grassland habitats (i.e., habitat code 6210 and 6170; EU Habitats Directive 92/43/EEC). The bedrock of the study area is calcareous, and the climate is temperate-oceanic, which is characterized by an annual mean temperature of $13^{\circ} \mathrm{C}$ and a mean precipitation of $865 \mathrm{~mm}$, with higher values in autumn and spring, and the minima in summer [34]. Figure 1 shows the monthly mean air temperatures and precipitation during the study period (January 2016-December 2018), when the precipitation that occurred from June to September $2016(374.2 \mathrm{~mm})$ was almost double that of the same period in 2017 (191.8 $\mathrm{mm})$ and 2018 (197.8 $\mathrm{mm})$.

\subsection{Study Site and Experimental Design}

In November 2015, an area homogenous for soil, vegetation and topographic conditions $\left(43^{\circ} 21^{\prime} 13.4^{\prime \prime}\right.$

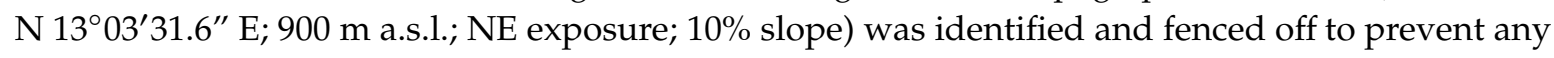
disturbance. The site was characterized by a semi-natural permanent grassland that was dominated by Bromus erectus and was considered as a priority habitat (i.e., $6210\left({ }^{*}\right)$ Semi-natural dry grasslands and scrubland facies on calcareous substrates (Festuco-Brometalia) ( ${ }^{*}$ important orchid sites), Council Directive 92/43/EEC). It belonged to the association Brizo mediae-Brometum erecti Bruno in Bruno and Covarelli 1968 corr. Biondi and Ballelli 1982. The soil was classified as Mollisol, according to the United States Department of Agriculture Soil Taxonomy system [35]. The soil texture from $0 \mathrm{~cm}$ to $20 \mathrm{~cm}$ in depth was clay loam, with a rocky component of $7 \%$, a pH of 6.79 , a total C content of $5.92 \%$, and a total $\mathrm{N}$ content of $5.25 \%$.

A complete randomized block design with three replicates was applied to test the responses of the grassland to different use regimes from 2016 to 2018, as: (i) customary management (CST), with herbage mowing performed by the end of June and by the end of October each year; (ii) intensive 
use (INT), with herbage mowing performed every month from April until the end of October each year, when the herbage production was available; (iii) under abandonment (ABN), with no herbage mowing performed throughout the study period. Each experimental unit was $2.0 \mathrm{~m} \times 2.0 \mathrm{~m}$. The herbage mowing within the experimental units was carried out every year using a bar mower (cutting height, $5 \mathrm{~cm}$ ) and a standard rake was used to collect and remove the cut herbage immediately after the mowing. For each experimental unit, the soil respiration, temperature, and water content were measured from March 2016 to October 2018, for a total of 52 surveys.

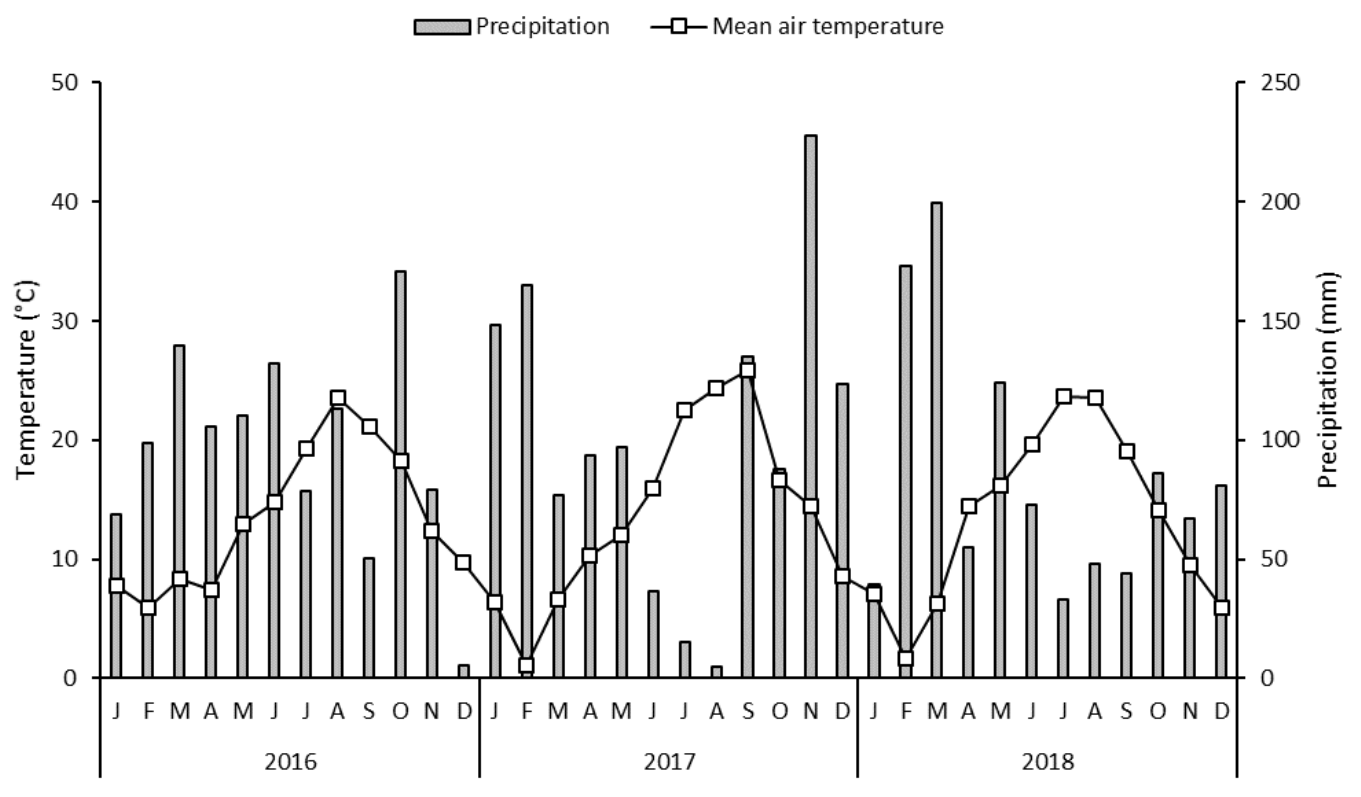

Figure 1. Monthly mean air temperatures and precipitation in the study area during the experimental period from 2016 to 2018 (source: Regione Marche, Servizio Protezione Civile).

\subsection{Measurement Descriptions}

For each experimental unit, one polyvinyl chloride collar was installed (inner diameter, $10 \mathrm{~cm}$; height, $10 \mathrm{~cm}$; with perforated walls), which was inserted $\sim 9 \mathrm{~cm}$ into the soil to measure total soil respiration. The measurements were performed in situ using a portable $\mathrm{CO}_{2}$ infrared gas analyzer with a soil respiration closed chamber (EGM-4 with SRC-1, PP-Systems, Hitchin, UK), equipped with a thermometer probe. For each measurement, soil temperature was measured at $10 \mathrm{~cm}$ soil depth. Soil water content was determined on soil samples collected from the top $10 \mathrm{~cm}$ layer, using oven drying at $105{ }^{\circ} \mathrm{C}$ to constant weight. Soil respiration, soil temperature, and soil water content were monitored between 9:00 am and 12:00 noon (standard time), to avoid efflux fluctuations [36].

\subsection{Data Analysis}

Two-way mixed analysis of variance (General linear model procedure for repeated measure) was carried out to assess the effect of time, mowing frequency as well as their interactions on seasonal mean soil respiration, temperature, and water content. When a significative interaction emerged, a Tukey test was carried out on mowing frequency to detect differences in each date of measurements. Conversely (i.e., with no significant interaction between mowing and time) only the main effect of mowing frequencies was compared with Tukey honest significant difference (HSD) tests. Data had been previously tested for normality distribution by Shapiro-Wilk's test and sphericity by Mauchly's test.

Seasonal mean soil respiration, temperature, and water content were calculated by linear interpolation between close dates of measurement, assuming a linear flux change between sampling days [37]. 
Regression analysis was used to determine the relationships between soil respiration and soil temperature and water content [38]. Breakpoints within the functional relationship between respiration and soil water content were detected with a piecewise regression approach. The following equations were used:

For soil respiration and soil water content:

$$
y=a+b x
$$

where $y$ is the measured soil respiration $\left(\mathrm{g} \mathrm{CO}_{2} \mathrm{~m}^{-2} \mathrm{~h}^{-1}\right), a$ and $b$ are the equation coefficients, and $x$ is the measured soil water content.

For soil respiration and soil temperature:

$$
y=a e^{b x}
$$

where $y$ is the measured soil respiration $\left(\mathrm{g} \mathrm{CO}_{2} \mathrm{~m}^{-2} \mathrm{~h}^{-1}\right), a$ and $b$ are the equation coefficients, and $x$ is the measured soil temperature.

\section{Results}

\subsection{Soil Water Content and Temperature Dynamics as Affected by Mowing Intensity}

Both the soil water content and temperature varied markedly throughout the study period, with similar trends across all three of the management treatments, customary (CST), intensive (INT), and abandonment $(\mathrm{ABN})$. In general, the peaks in the temperature coincided with the minimum water content in summer, while the minimum soil temperatures were recorded in winter along with the highest soil moisture (Figure 2A,B).

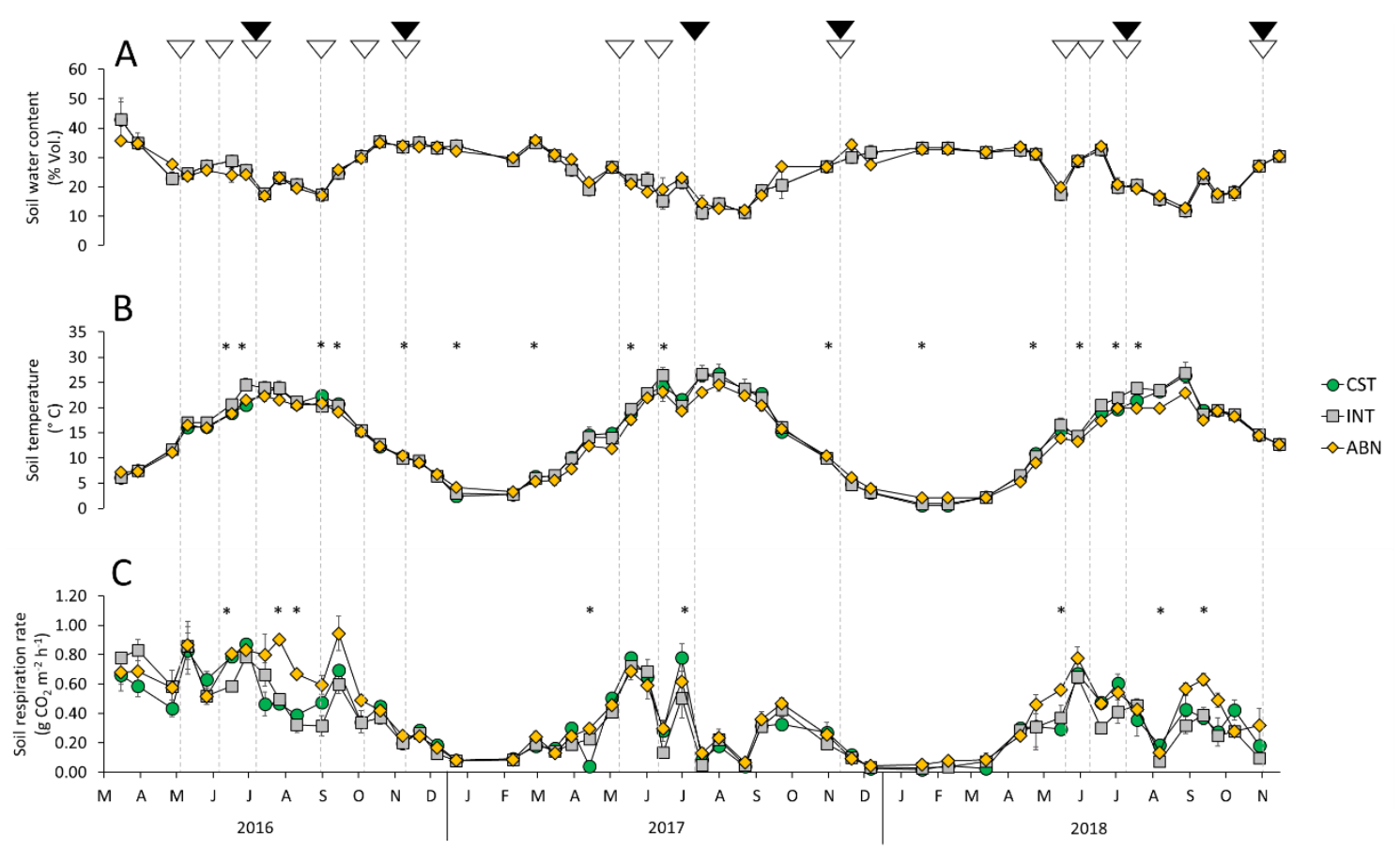

Figure 2. Seasonal variations of the soil water content (A, $10 \mathrm{~cm}$ depth), soil temperature $(\mathbf{B}, 10 \mathrm{~cm}$ depth), and soil respiration (C) during the study period from April 2016 to November 2018. Black triangles, dates of the mowing applied for customary management (CST); white triangles, dates of the mowing applied for intensive use (INT); no mowing was applied for abandonment (ABN). Vertical bars, standard errors. Data are means of three replicates per treatment. ${ }^{*}, p<0.05$. 
The soil water content at $10 \mathrm{~cm}$ in depth ranged from $11.12 \%$ to $35.45 \%$ for CST, from $10.13 \%$ to $36.18 \%$ for INT, and from $12.15 \%$ to $35.83 \%$ for ABN. During the 3 year study period, the mean soil water content at $10 \mathrm{~cm}$ depth was $24.89 \%, 24.24 \%$, and $25.07 \%$ for CST, INT, and ABN, respectively.

The soil temperatures at $10 \mathrm{~cm}$ depth ranged from $0.63{ }^{\circ} \mathrm{C}$ to $26.72{ }^{\circ} \mathrm{C}$ for CST, from $0.98{ }^{\circ} \mathrm{C}$ to $26.90{ }^{\circ} \mathrm{C}$ for INT, and from $2.10^{\circ} \mathrm{C}$ to $24.53^{\circ} \mathrm{C}$ for ABN. During the 3 year study period, the mean soil temperatures at $10 \mathrm{~cm}$ depth were $15.39^{\circ} \mathrm{C}, 15.71^{\circ} \mathrm{C}$, and $14.58^{\circ} \mathrm{C}$ for CST, INT, and ABN, respectively.

Both soil water content and temperature changed over the growing or vegetative periods of the monitored years, however, within the dates of measurements, mowing did not affect soil water content, but occasionally altered soil temperature (Table 1 ).

Table 1. Repeated measure ANOVA for soil water content, temperature, and respiration during the growing periods $(\mathrm{G})$ and the vegetative stasis (S) for customary management (CST), intensive use (INT), and abandonment (ABN). Different letters indicate significant differences (Tukey HSD test, $p<0.05$ ).

\begin{tabular}{|c|c|c|c|c|c|c|c|c|c|c|c|c|}
\hline \multirow{3}{*}{ Variable } & \multirow{3}{*}{$\begin{array}{l}\text { Source of } \\
\text { Variation }\end{array}$} & \multicolumn{5}{|c|}{$p$ Values } & \multirow{3}{*}{$\begin{array}{l}\text { Mowing } \\
\text { Regime }\end{array}$} & \multicolumn{5}{|c|}{ Seasonal Mean \pm Standard Error } \\
\hline & & \multicolumn{2}{|c|}{2016} & \multicolumn{2}{|c|}{2017} & \multirow{2}{*}{$\frac{2018}{G}$} & & \multicolumn{2}{|c|}{2016} & \multicolumn{2}{|c|}{2017} & \multirow{2}{*}{$\begin{array}{c}2018 \\
G\end{array}$} \\
\hline & & G & $\mathbf{S}$ & G & $\mathrm{S}$ & & & G & $\mathbf{S}$ & G & $\mathbf{S}$ & \\
\hline \multirow{3}{*}{$\begin{array}{c}\text { Soil water } \\
\text { content (\% Vol.) }\end{array}$} & Time & 0.01 & 0.01 & 0.01 & 0.06 & 0.01 & CST & $\begin{array}{l}26.91 \\
\pm 0.49\end{array}$ & $\begin{array}{l}32.11 \\
\pm 0.22\end{array}$ & $\begin{array}{l}19.28 \\
\pm 0.88\end{array}$ & $\begin{array}{l}31.92 \\
\pm 0.44\end{array}$ & $\begin{array}{l}22.62 \\
\pm 0.63\end{array}$ \\
\hline & Mowing & 0.43 & 0.72 & 0.55 & 0.34 & 0.20 & INT & $\begin{array}{l}26.13 \\
\pm 0.81\end{array}$ & $\begin{array}{l}30.89 \\
\pm 0.70\end{array}$ & $\begin{array}{r}19.29 \\
\pm 0.29\end{array}$ & $\begin{array}{l}30.95 \\
\pm 0.41\end{array}$ & $\begin{array}{l}22.21 \\
\pm 0.20\end{array}$ \\
\hline & $\begin{array}{l}\text { Time } \times \\
\text { Mowing }\end{array}$ & 0.49 & 0.30 & 0.29 & 0.08 & 0.95 & $\mathrm{ABN}$ & $\begin{array}{r}25.94 \\
\pm 0.51\end{array}$ & $\begin{array}{l}32.47 \\
\pm 0.50\end{array}$ & $\begin{array}{r}19.98 \\
\pm 0.41\end{array}$ & $\begin{array}{l}32.05 \\
\pm 0.61\end{array}$ & $\begin{array}{l}23.16 \\
\pm 0.59\end{array}$ \\
\hline \multirow{3}{*}{$\begin{array}{l}\text { Soil temperature } \\
\left({ }^{\circ} \mathrm{C}\right)\end{array}$} & Time & 0.01 & 0.01 & 0.01 & 0.01 & 0.01 & CST & $\begin{array}{l}16.85 \\
\pm 0.52\end{array}$ & $\begin{array}{c}6.77 \\
\pm 0.31\end{array}$ & $\begin{aligned} & 20.10 \\
\pm & 0.85 \mathrm{ab}\end{aligned}$ & $\begin{array}{c}3.45 \\
\pm 0.21\end{array}$ & $\begin{array}{l}18.07 \\
\pm 0.60\end{array}$ \\
\hline & Mowing & 0.13 & 0.73 & 0.01 & 0.16 & 0.10 & INT & $\begin{array}{l}17.34 \\
\pm 0.53\end{array}$ & $\begin{array}{c}6.76 \\
\pm 0.50\end{array}$ & $\begin{array}{c}20.18 \\
\pm 0.95 \mathrm{a}\end{array}$ & $\begin{array}{c}3.54 \\
\pm 0.19\end{array}$ & $\begin{array}{l}18.64 \\
\pm 0.83\end{array}$ \\
\hline & $\begin{array}{l}\text { Time } \times \\
\text { Mowing }\end{array}$ & 0.01 & 0.01 & 0.01 & 0.01 & 0.02 & $\mathrm{ABN}$ & $\begin{array}{c}16.44 \\
\pm 0.28\end{array}$ & $\begin{array}{c}6.58 \\
\pm 0.27\end{array}$ & $\begin{array}{c}18.57 \\
\pm 0.73 b\end{array}$ & $\begin{array}{c}3.92 \\
\pm 0.05\end{array}$ & $\begin{array}{r}16.80 \\
\pm 0.25\end{array}$ \\
\hline \multirow{3}{*}{$\begin{array}{l}\text { Soil respiration } \\
\left(\mathrm{g} \mathrm{CO}_{2} \mathrm{~m}^{-2} \mathrm{~h}^{-1}\right)\end{array}$} & Time & 0.01 & 0.01 & 0.01 & 0.01 & 0.01 & CST & $\begin{aligned} & 0.56 \\
\pm & 0.01 \mathrm{ab}\end{aligned}$ & $\begin{array}{c}0.19 \\
\pm 0.02\end{array}$ & $\begin{array}{c}0.35 \\
\pm 0.02\end{array}$ & $\begin{array}{c}0.05 \\
\pm 0.01\end{array}$ & $\begin{array}{c}0.37 \\
\pm 0.05\end{array}$ \\
\hline & Mowing & 0.04 & 0.40 & 0.28 & 0.23 & 0.23 & INT & $\begin{aligned} & 0.54 \\
\pm & 0.01 \mathrm{~b}\end{aligned}$ & $\begin{array}{c}0.16 \\
\pm 0.01\end{array}$ & $\begin{array}{c}0.33 \\
\pm 0.02\end{array}$ & $\begin{array}{c}0.06 \\
\pm 0.01\end{array}$ & $\begin{array}{c}0.32 \\
\pm 0.04\end{array}$ \\
\hline & $\begin{array}{l}\text { Time } \times \\
\text { Mowing }\end{array}$ & 0.01 & 0.08 & 0.01 & 0.82 & 0.01 & $\mathrm{ABN}$ & $\begin{aligned} & 0.67 \\
\pm & 0.05 \mathrm{a}\end{aligned}$ & $\begin{array}{c}0.18 \\
\pm 0.01\end{array}$ & $\begin{array}{c}0.37 \\
\pm 0.03\end{array}$ & $\begin{array}{c}0.07 \\
\pm 0.01\end{array}$ & $\begin{array}{c}0.45 \\
\pm 0.01\end{array}$ \\
\hline
\end{tabular}

Seasonal mean soil water content was never affected by the combination of time and mowing regimes. Conversely, the time was found to significantly affect the seasonal mean soil water content of each mowing regime with the exception of the 2017 stasis $(p=0.06)$. Mowing frequencies did not have significant effects in any of the monitored growing or vegetative periods (Table 1).

For seasonal mean soil temperature, a significant interaction between time and mowing regime was observed in all of the growing and vegetative stasis periods throughout the monitoring period (Table 1). Higher soil temperatures were occasionally observed in INT compared to ABN after the mowing performed in spring for INT in each year of the monitoring period. Conversely, during the vegetative stasis, occasional significantly higher soil temperatures were observed in $\mathrm{ABN}$ compared to the other treatments (Figure 2B).

\subsection{Soil Respiration Dynamics as Affected by Mowing Intensity}

The soil respiration varied markedly among and within the years of the study. This generally following the changes in the soil temperature over most of the year, except in summer, when the soil respiration followed changes in the soil water content (Figure 2C). Multiple peaks of soil respiration were observed for all three of the treatments throughout the 3 year monitoring period. In particular, in 2016, all of the treatments showed fluctuating dynamics that were characterized by three peaks for the soil respiration between March and October, with a less marked trend for ABN compared to CST and INT. In 2017, the first peak of the soil respiration was in the third week of May for all of the treatments $\left(0.78,0.72,0.69 \mathrm{~g} \mathrm{CO}_{2} \mathrm{~m}^{-2} \mathrm{~h}^{-1}\right.$ for CST, INT, ABN, respectively). This was followed by a marked drop in the soil respiration and a subsequent second peak $\left(0.78,0.50,0.62 \mathrm{~g} \mathrm{CO}_{2} \mathrm{~m}^{-2} \mathrm{~h}^{-1}\right.$ 
for CST, INT, ABN, respectively). In 2018, the first peak of the soil respiration occurred at the end of May for all of the treatments $\left(0.67,0.65,0.78 \mathrm{~g} \mathrm{CO}_{2} \mathrm{~m}^{-2} \mathrm{~h}^{-1}\right.$ for CST, INT, ABN, respectively), with a less pronounced subsequent drop in the soil respiration compared to 2016 and 2017. The second peak of the soil respiration in 2018 occurred at the end of July for CST $\left(0.60 \mathrm{~g} \mathrm{CO}_{2} \mathrm{~m}^{-2} \mathrm{~h}^{-1}\right)$ and in the third week of September for ABN $\left(0.63 \mathrm{~g} \mathrm{CO}_{2} \mathrm{~m}^{-2} \mathrm{~h}^{-1}\right)$, while there was no second peak here for INT (Figure 2C). During the whole study period, the soil respiration ranged from 0.02 to $0.87 \mathrm{~g} \mathrm{CO}_{2}$ $\mathrm{m}^{-2} \mathrm{~h}^{-1}$ for CST, from 0.03 to $0.94 \mathrm{~g} \mathrm{CO}_{2} \mathrm{~m}^{-2} \mathrm{~h}^{-1}$ for INT, and from 0.05 to $0.94 \mathrm{~g} \mathrm{CO}_{2} \mathrm{~m}^{-2} \mathrm{~h}^{-1}$ for $\mathrm{ABN}$ (Figure 2C). During the 3 year study period, the mean soil respiration was $0.36 \mathrm{~g} \mathrm{CO}_{2} \mathrm{~m}^{-2} \mathrm{~h}^{-1}$, $0.33 \mathrm{~g} \mathrm{CO}_{2} \mathrm{~m}^{-2} \mathrm{~h}^{-1}$, and $0.41 \mathrm{~g} \mathrm{CO}_{2} \mathrm{~m}^{-2} \mathrm{~h}^{-1}$ for CST, INT, and ABN, respectively.

Soil respiration changed over time and, within the dates of measurements, it was occasionally affected by the mowing regime (Table 1). In general, seasonal mean soil respiration was found to be much higher during the growing period compared to vegetational stasis for all the treatments (Table 1). A significant interaction between time and mowing regimes emerged in all the growing seasons while seasonal mean soil respiration was found to be lower in INT compared to ABN only during the 2016 growing season.

Within the 2016 growing period, the first cut performed in INT had no effect on the soil respiration rates, which were $0.83,0.85$, and $0.86 \mathrm{~g} \mathrm{CO}_{2} \mathrm{~m}^{-2} \mathrm{~h}^{-1}$ in CST, INT, and ABN, respectively (Figure 2C). Conversely, approximately 2 weeks after the second mowing performed for INT, a significant decrease in soil respiration was observed in INT $\left(0.59 \mathrm{~g} \mathrm{CO}_{2} \mathrm{~m}^{-2} \mathrm{~h}^{-1}\right)$ compared to CST $\left(0.79 \mathrm{~g} \mathrm{CO}_{2} \mathrm{~m}^{-2} \mathrm{~h}^{-1}\right)$ and $\operatorname{ABN}\left(0.81 \mathrm{~g} \mathrm{CO}_{2} \mathrm{~m}^{-2} \mathrm{~h}^{-1}\right)$. After the first mowing for CST (i.e., the third mowing for INT, Figure 2C) both CST and INT showed significantly lower soil $\mathrm{CO}_{2}$ emission compared to the other treatment $(0.39$, 0.32 , and $0.67 \mathrm{~g} \mathrm{CO}_{2} \mathrm{~m}^{-2} \mathrm{~h}^{-1}$ in CST, INT, and ABN, respectively).

Within the 2017 growing season, a significant decrease in soil respiration was observed only after the second mowing performed in INT when CST was higher $\left(0.78 \mathrm{~g} \mathrm{CO}_{2} \mathrm{~m}^{-2} \mathrm{~h}^{-1}\right)$ than INT $(0.50 \mathrm{~g}$ $\mathrm{CO}_{2} \mathrm{~m}^{-2} \mathrm{~h}^{-1}$ ). Despite showing always lower $\mathrm{CO}_{2}$ emissions, the mowing performed in CST and/or INT did not result in significant emissions until the end of the 2017 growing season.

During the 2018 growing season, the first two mowings performed in INT did not result in any differences in terms of soil respiration among the treatments. However, approximately one month after the first mowing performed for CST (i.e., the third mowing for INT, Figure $2 \mathrm{C}$ ), the soil $\mathrm{CO}_{2}$ emission was higher for CST $\left(0.19 \mathrm{~g} \mathrm{CO}_{2} \mathrm{~m}^{-2} \mathrm{~h}^{-1}\right)$ compared to INT $\left(0.07 \mathrm{~g} \mathrm{CO}_{2} \mathrm{~m}^{-2} \mathrm{~h}^{-1}\right)$.

In general, the soil respiration for CST decreased after each mowing, with a sharper decrease after the first compared to the second. Similarly, the soil respiration for INT decreased after each mowing, except for those performed in the first week of June 2016 and in the second week of May 2018. In general, the soil respiration decreased more sharply for the mowing events performed for CST, compared to INT. For ABN, the soil respiration was generally higher than for CST and INT, especially in the periods after the mowing events, with more marked differences during 2016, compared to 2017 and 2018 (Figure 2C).

\subsection{Relationships Between Soil Respiration, Soil Water Content, and Temperature}

The regression analysis showed that soil moisture was the main driver of soil respiration below a soil water content threshold that varied little among treatments (18.23-22.71\%). Above the thresholds, soil temperature was the main driver of soil respiration (Figure 3).

A positive correlation between soil water content and soil respiration was observed when the soil water content was below $22.51 \%, 22.71 \%$, and $18.23 \%$ in CST, INT, and ABN, respectively. In that case, the linear model (Equation (1)) explained $42 \%, 44 \%$, and $46 \%$ of the seasonal variation in the soil respiration for CST, INT, and ABN, respectively $(p<0.05)$. Above such threshold, a negative and weaker relationship was observed for soil respiration and soil water content only in CST and $\mathrm{ABN}$, explaining $21 \%$ and $26 \%$ of the soil respiration seasonal variation, respectively. A not significant relationship was found in INT. 
In contrast, a positive and significant relationship was observed with soil temperature where the exponential model (Equation (2)) explained 66\%,63\%, and 77\% of the seasonal variation in the soil respiration for CST, INT, and ABN, respectively $(p<0.05)$.

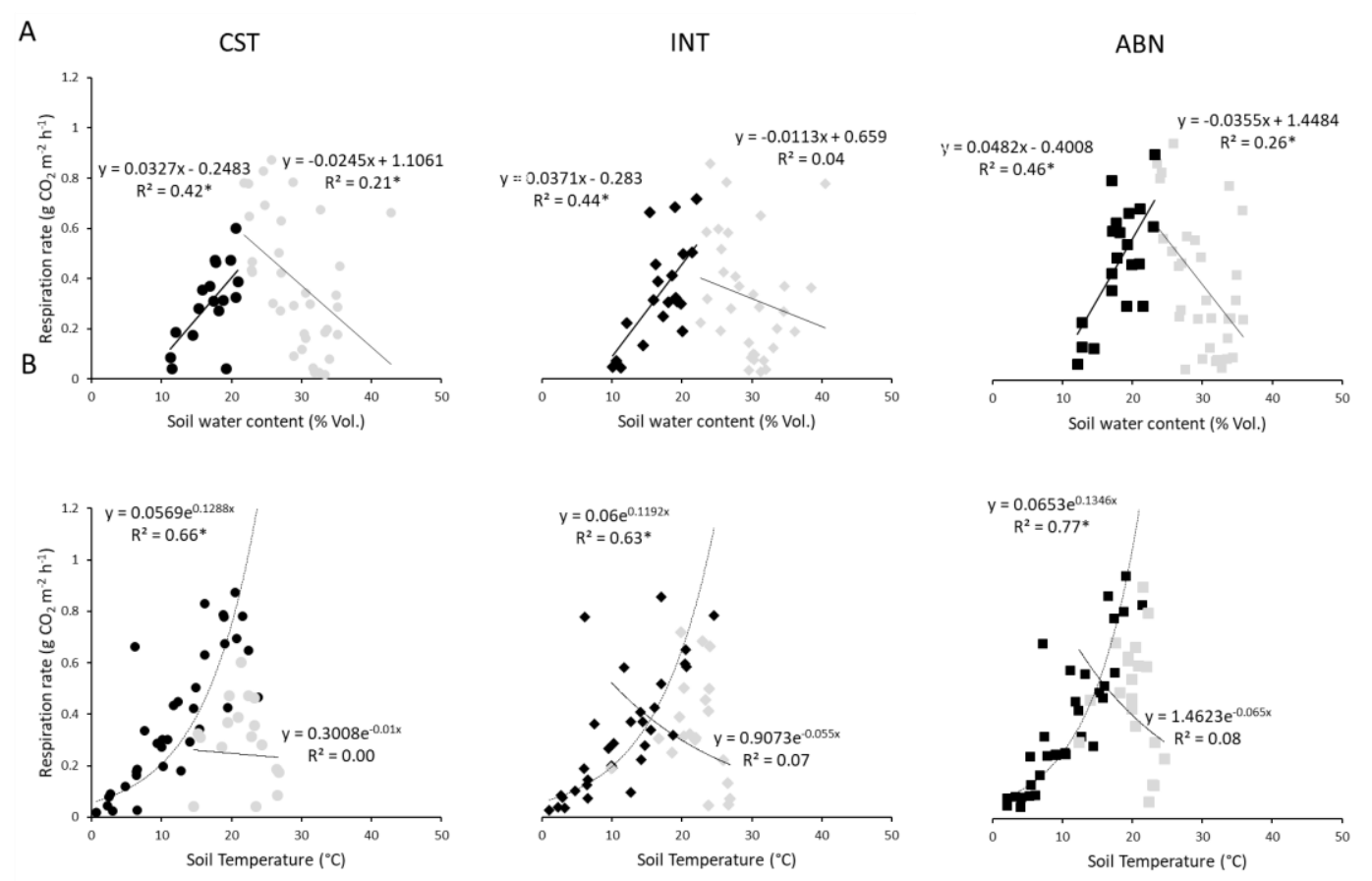

Figure 3. Relationships between the variations in the soil respiration and the soil water content at $10 \mathrm{~cm}$ depth (A) and the soil temperature at $10 \mathrm{~cm}$ depth (B) for customary management (CST), intensive use (INT), and abandonment (ABN). Black symbols refer to data below the threshold for soil water content modeling and above the threshold for soil temperature modeling. Gray symbols refer to data above the threshold for soil water content modeling and below the threshold for soil temperature modeling. Data are means of three replicates per treatment. ${ }^{*} p<0.05$.

\section{Discussion}

\subsection{Relationships Between Soil Respiration, Water Content and Temperature}

A role for grasslands in climate change mitigation is widely recognized, and the numerous studies that have been carried out recently testify their importance at the global level [5,24,26,32,39-41]. Future climate scenarios in southern Europe suggest that changes in annual temperatures, precipitation patterns, and atmospheric $\mathrm{CO}_{2}$ concentrations might negatively alter grassland biodiversity and the associated ecosystem services, including regulating services linked to carbon cycling, especially in areas with low summer rainfall $[5,41]$. It is well known that the soil respiration of grasslands is largely driven by the soil temperature and the soil moisture [13,26] although the data tend to be context-dependent and related to human disturbances, such as management practices (e.g., grazing, fertilization) and changes in land use [6].

In the present study, the soil temperature was the main driver of the soil respiration only when the soil water content was not a limiting factor. Indeed, the soil respiration dynamics generally followed the soil temperature trends from autumn to the end of spring, while in summer, its pattern was bound to the soil water content dynamics (Figure 2). This was confirmed by the regression analysis that highlighted the relationships between the soil respiration and the soil water content under certain thresholds (Figure 3). Similar data have been reported in other studies carried out in areas with dry summer seasons or where the main limitation is water shortage (e.g., [12,41]). In line with these studies, when water was a limiting factor here, the soil respiration increased sharply, together with the increase in the soil water content due to the rainfall events (Figure 2). Such soil respiration 'pulses' are typical of 
Mediterranean regions, and they are associated with rainfall events during the prolonged dry season and are controlled by both biotic (e.g., fine roots, mycorrhizal, and microbial activities) and abiotic (e.g., $\mathrm{CO}_{2}$ released by soil carbonates) factors [12].

\subsection{The Effects of Management Practices on Soil Water Content and Temperature}

The soil water content was always influenced by time except for the 2017 stasis, but it was never influenced either by mowing or by the mowing $\times$ time interaction. In agreement with the present study, mowing did not affect the soil water content of tall grass prairies [25] or semi-arid grasslands [24,26]. In contrast, herbage mowing significantly altered soil water content in alpine meadows only when soil temperature was increased with infrared heaters [27]. As suggested by [26], the lack of a significant effect of herbage mowing on this study may be attributed to an offset of enhanced evaporation by decreased transpiration. Indeed, for both CST and INT the mowing caused a drastic reduction of the photosynthetic tissues that due to the aridity conditions in summer (i.e., high temperature and low rainfall) did not return to grow, except belatedly in autumn. At the same time, the low transpiration for $\mathrm{ABN}$ may be related to a low photosynthetic activity due to sward aging.

The mowing regime had a significant effect on soil temperatures measured at $10 \mathrm{~cm}$. As observed by [24], herbage removal by mowing exposes soil to higher incident solar radiation and this might result in a stimulation of both microbial and plant root activities. At the same time, the shading effect of $A B N$ is expected to result in lower soil temperature [25]. Indeed, in the present study a higher mean soil temperature was found in INT compared with ABN in the 2017 growing season (Table 1). Despite that, during the vegetative stasis, when significant differences emerged for soil respiration, $\mathrm{ABN}$ was found to be higher compared to CST and INT (Figure 2C). This may be attributed to a "shelter" effect of $\mathrm{ABN}$ which still had a relevant sward biomass.

Despite the mowing frequency affecting seasonal mean soil temperature in the 2017 growing season, this did not result in differences in terms of seasonal mean soil respiration rates within the same period.

\subsection{The Effects of Management Practices on Soil Respiration}

The results of the effects of use intensity on the soil respiration for grasslands tend to be highly context-dependent, and sometimes contrasting because many other biotic and abiotic factors can affect soil respiration (e.g., grazing, fertilization, substrate supply) and contribute to the soil $\mathrm{CO}_{2}$ release [6]. For example, as reported by [26] for semi-dry grasslands in inner Mongolia, the soil respiration was not affected by mowing and, contrary to expectation this did not alter the soil water content nor the supply of $C$ substrate to the soil microorganisms. On the other hand, as reported by [24] for similar semi-dry grasslands, mowing significantly decreased the soil respiration, because root production was significantly reduced after the mowing.

In the present case study, the effects of mowing on the soil respiration generally emerged 1 week or 2 weeks after its application, with significant effects only in the 2016 growing season. The effects of mowing led to soil respiration suppression that is explainable as a reduction in the photosynthetic assimilates supply from the above-ground plant parts to the roots [22], and in the labile C substrate for the rhizosphere microorganisms [25].

In the present case study, this mowing effect on the soil respiration was more visible in 2016, compared to 2017 and 2018, because of the limited amount of rainfall that occurred in these latter 2 years that might suppress both the microbial activities [42] and the root respiration [40]. Some studies have reported that mowing has an indirect effect on the soil respiration due to herbage removal and exposure of the soil to higher incident solar radiation, which might stimulate the soil microbial activity due to the soil temperature increase [24]. However, this was not the case for the present study as the soil temperature was not influenced by mowing frequency in the 2016 growing season. 
These limited effects of mowing on the soil respiration of this Bromus erectus-dominated grassland regardless of use intensity suggest that future studies should also consider the effects on microbial respiration [6] and the potential synergies and trade-offs between the other ecosystem services [16,39].

\section{Conclusions}

The different mowing frequency had no effect on soil moisture over the 3 year monitoring period. Conversely, it occasionally changed the soil temperature both in the growing season and vegetative stasis. At any rate, such changes in soil temperature did not have any impact on seasonal mean soil respiration among the treatments, except for the 2016 growing season when the intensive use showed lower soil seasonal mean respiration rates compared to the abandonment. Such differences in soil $\mathrm{CO}_{2}$ emissions were imputable only to the effect of mowing and not to the alteration of soil water content or temperature.

Within the same mowing frequency, the soil temperature was the main driver of the soil respiration only when the soil water content was above a threshold. Below this threshold, soil respiration was mainly controlled by the soil water content, as highlighted by soil respiration pulses that occurred after rainfall events during prolonged dry seasons.

These effects on soil respiration, that emerged only in the first growing season with high rainfall, suggest that in this study site, a more intensive use would not have significative impacts on soil respiration of Bromus erectus-dominated grasslands. The integrated analysis of multiple case studies, also using modeling applications, would contribute to confirming the dynamics observed for the whole Bromus erectus-dominated grassland ecosystem, regardless of the study site.

Future studies should include aspects such as the contributions of the root, mycorrhizal, and microbial respiration in the light of climate change, especially considering the project scenarios of the seasonal redistribution of precipitation patterns, with a focus on the effects of rainfall on prolonged dry periods.

Author Contributions: Conceptualization, M.F., L.T., M.T., P.D.; methodology, M.F., L.T.; formal analysis, M.F., L.T., P.D., M.T., N.B., L.F.; investigations, M.F., L.T., N.B.; resources, L.T., L.F., G.T., M.A.; data curation, M.F., L.T.; writing — original draft preparation, M.F., L.T., M.T., P.D.; writing—review and editing, M.F., P.D., M.A., G.T., A.W.K.-M.; supervision, M.T., P.D., R.S., A.W.K.-M.; project administration, M.T., P.D.; funding acquisition, M.T., P.D., R.S. All authors have read and agreed to the published version of the manuscript.

Funding: This research was funded by Joint Programming Initiative for Agriculture, Climate Change, and Food Security (JPI FACCE MACSUR 2-D.M. 24064/7303/2015-www.MACSUR.eu), as funded for the Italian partnership by the Italian Ministry of Agricultural, Food and Forestry Policies.

Acknowledgments: This study was carried out with the support of the project PACTORES: PAstoral ACTORs, Ecosystem services and society as key elements of agro-pastoral systems in the Mediterranean, ERANETMED "EURO-MEDITERRANEAN Cooperation through ERANET joint activities and beyond"- Joint Transnational Call 2016-Environmental challenges and solutions for vulnerable communities (ERANETMED2-72-303); FORESTPAS2000 “Foreste e Pascoli della Rete Natura 2000-Indirizzi di gestione sostenibile in Italia centrale" (MIPAAF D.M. 29474 28.10.2010). We would like to thank the anonymous reviewers for their valuable suggestions and corrections that helped to improve this manuscript.

Conflicts of Interest: The authors declare that they have no conflicts of interest. The funders had no role in the design of the study, in the collection, analysis or interpretation of the data, in the writing of the manuscript, or in the decision to publish the results.

\section{References}

1. Smith, P.; Bustamante, M.; Ahammad, H.; Clark, H.; Dong, H.; Elsiddig, E.A.; Haberl, H.; Harper, R.; House, J.; Jafari, M.; et al. Agriculture, forestry and other land use (AFOLU). In Climate Change 2014: Mitigation of Climate Change. Contribution of Working Group III to the Fifth Assessment Report of the Intergovernmental Panel on Climate Change; Cambridge University Press: Cambridge, UK; New York, NY, USA, 2014.

2. Raich, J.W.; Schlesinger, W.H. The global carbon dioxide flux in soil respiration and its relationship to vegetation and climate. Tellus B 1992, 44, 81-99. [CrossRef] 
3. Xu, M.; Shang, H. Contribution of soil respiration to the global carbon equation. J. Plant Physiol. 2016, 203, 16-28. [CrossRef] [PubMed]

4. Rustad, L.; Huntington, T.G.; States, U.; Survey, G.; Boone, R.D. Controls on Soil Respiration: Implications for Climate Change Controls on soil respiration: Implications for climate change. Biogeochemistry 2000, 48, 1-6. [CrossRef]

5. Hopkins, A.; Del Prado, A. Implications of climate change for grassland in Europe: Impacts, adaptations and mitigation options: A review. Grass Forage Sci. 2007, 62, 118-126. [CrossRef]

6. Wang, W.; Fang, J. Soil respiration and human effects on global grasslands. Glob. Planet. Chang. 2009, 67, 20-28. [CrossRef]

7. O'Mara, F.P. The role of grasslands in food security and climate change. Ann. Bot. 2012, 110, 1263-1270. [CrossRef]

8. Smith, P. Land use change and soil organic carbon dynamics. Nutr. Cycl. Agroecosyst. 2008, 81, $169-178$. [CrossRef]

9. Li, W.; Wang, J.; Zhang, X.; Shi, S.; Cao, W. Effect of degradation and rebuilding of artificial grasslands on soil respiration and carbon and nitrogen pools on an alpine meadow of the Qinghai-Tibetan Plateau. Ecol. Eng. 2018, 111, 134-142.

10. Hoffmann, I.; From, T.; Boerma, D. Ecosystem Services Provided by Livestock Species and Breeds, with Special Consideration to the Contributions of Small-Scale Livestock Keepers and Pastoralists. FAO Commission on Genetic Resources for Food and Agriculture. Background Study Paper 66(1). 2014. Available online: http://www.fao.org/3/a-at598e.pdf (accessed on 27 July 2019).

11. Velthof, G.L.; Lesschen, J.P.; Schils, R.L.M.; Smit, A.; Elbersen, B.S.; Hazeu, G.W.; Mucher, C.A.; Oenema, O. Grassland Areas, Production and Use; Alterra Wageningen UR: Wageningen, The Netherlands, 2014.

12. Almagro, M.; López, J.; Querejeta, J.I.; Martínez-Mena, M. Temperature dependence of soil CO2 efflux is strongly modulated by seasonal patterns of moisture availability in a Mediterranean ecosystem. Soil Biol. Biochem. 2009, 41, 594-605. [CrossRef]

13. Rong, Y.; Ma, L.; Johnson, D.A.; Yuan, F. Soil respiration patterns for four major land-use types of the agro-pastoral region of northern China. Agric. Ecosyst. Environ. 2015, 213, 142-150. [CrossRef]

14. Calaciura, B.; Spinelli, O. Management of Natura 2000 Habitats. In 6210 Semi-Natural Dry Grasslands and Scrubland Facies on Calcareous Substrates (Festuco-Brometalia) (* Important Orchid Sites); European Commission: Brussels, Belgium, 2008; ISBN 978-92-79-08326-6.

15. Wilson, J.W.; Peet, R.K.; Dengler, J.; Pärtel, M. Plant species richness: The world records. J. Veg. Sci. 2012, 23, 796-802. [CrossRef]

16. D’Ottavio, P.; Francioni, M.; Trozzo, L.; Sedić, E.; Budimir, K.; Avanzolini, P.; Trombetta, M.F.; Porqueddu, C.; Santilocchi, R.; Toderi, M. Trends and approaches in the analysis of ecosystem services provided by grazing systems: A review. Grass Forage Sci. 2018, 73, 15-25. [CrossRef]

17. Alcamo, J.; Ash, N.J.; Butler, C.D.; Callicot, J.B.; Capistrano, D.; Carpenter, S.R. Ecosystems and Human Well-Being: A Framework for Assessment; Island Press: Washington, DC, USA, 2003; ISBN 1597260401.

18. Toderi, M.; Francioni, M.; Seddaiu, G.; Roggero, P.P.; Trozzo, L.; D’Ottavio, P. Bottom-up design process of agri-environmental measures at a landscape scale: Evidence from case studies on biodiversity conservation and water protection. Land Use Policy 2017, 68, 295-305. [CrossRef]

19. D'Ottavio, P.; Ziliotto, U. Effect of different management on the production characteristics of mountain permanent meadows. Ital. J. Anim. Sci. 2003, 2, 249-251.

20. Bonanomi, G.; Caporaso, S.; Allegrezza, M. Effects of nitrogen enrichment, plant litter removal and cutting on a species-rich Mediterranean calcareous grassland. Plant Biosyst. 2009, 143, 443-455. [CrossRef]

21. Tesei, G.; D’Ottavio, P.; Toderi, M.; Ottaviani, C.; Pesaresi, S.; Francioni, M.; Trozzo, L.; Allegrezza, M. Restoration strategies for grasslands colonized by Asphodel-dominant communities. Grassl. Sci. 2019, 1-10. [CrossRef]

22. Bahn, M.; Rodeghiero, M.; Anderson-Dunn, M.; Dore, S.; Gimeno, C.; Drösler, M.; Williams, M.; Ammann, C.; Berninger, F.; Flechard, C.; et al. Soil respiration in European grasslands in relation to climate and assimilate supply. Ecosystems 2008, 11, 1352-1367. [CrossRef]

23. Zhao, F.; Ren, C.; Shelton, S.; Wang, Z.; Pang, G.; Chen, J.; Wang, J. Grazing intensity influence soil microbial communities and their implications for soil respiration. Agric. Ecosyst. Environ. 2017, 249, 50-56. [CrossRef] 
24. Wei, L.; Liu, J.; Su, J.; Jing, G.; Zhao, J.; Cheng, J.; Jin, J. Effect of clipping on soil respiration components in temperate grassland of Loess Plateau. Eur. J. Soil Biol. 2016, 75, 157-167. [CrossRef]

25. Wan, S.; Luo, Y. Substrate regulation of soil respiration in a tallgrass prairie: Results of a clipping and shading experiment. Glob. Biogeochem. Cycles 2003, 17, 1-11. [CrossRef]

26. Han, Y.; Zhang, Z.; Wang, C.; Jiang, F.; Xia, J. Effects of mowing and nitrogen addition on soil respiration in three patches in an oldfield grassland in Inner Mongolia. J. Plant Ecol. 2011, 5, 219-228. [CrossRef]

27. Zhu, X.; Luo, C.; Wang, S.; Zhang, Z.; Cui, S.; Bao, X.; Jiang, L.; Li, Y.; Li, X.; Wang, Q.; et al. Effects of warming, grazing/cutting and nitrogen fertilization on greenhouse gas fluxes during growing seasons in an alpine meadow on the Tibetan Plateau. Agric. For. Meteorol. 2015, 214-215, 506-514. [CrossRef]

28. Francioni, M.; D’Ottavio, P.; Lai, R.; Trozzo, L.; Budimir, K.; Foresi, L.; Kishimoto-Mo, A.W.; Baldoni, N.; Allegrezza, M.; Tesei, G.; et al. Seasonal soil respiration Dynamics and Carbon-Stock Variations in Mountain Permanent Grasslands Compared to Arable Lands. Agriculture 2019, 9, 165. [CrossRef]

29. Gavrichkova, O.; Moscatelli, M.C.; Kuzyakov, Y.; Grego, S.; Valentini, R. Influence of defoliation on CO2 efflux from soil and microbial activity in a Mediterranean grassland. Agric. Ecosyst. Environ. 2010, 136, 87-96. [CrossRef]

30. Bahn, M.; Knapp, M.; Garajova, Z.; Pfahringer, N.; Cernusca, A. Root respiration in temperate mountain grasslands differing in land use. Glob. Chang. Biol. 2006, 12, 995-1006. [CrossRef]

31. Cherwin, K.; Knapp, A. Unexpected patterns of sensitivity to drought in three semi-arid grasslands. Oecologia 2012, 169, 845-852. [CrossRef]

32. Zhu, L.; Johnson, D.A.; Wang, W.; Ma, L.; Rong, Y. Grazing effects on carbon fluxes in a Northern China grassland. J. Arid Environ. 2015, 114, 41-48. [CrossRef]

33. Caballero, R.; Fernández-gonzález, F.; Badia, R.; Molle, G.; Roggero, P.; Bagella, S.; D’Ottavio, P.; Papanastasis, V.; Fotiadis, G.; Sidiropoulou, A.; et al. Grazing Systems and Biodiversity in Mediterranean Areas: Spain, Italy and Greece. Pastos 2009, 39, 9-154.

34. Allegrezza, M. Vegetazione e paesaggio vegetale della dorsale del Monte San Vicino (Appennino centrale). Fitosociologia 2003, 40, 3-118.

35. Soil Survey Staff. Keys to Soil Taxonomy, 12th ed.; Soil Conservation Services: Washington, DC, USA, 2014; Volume 12, p. 410.

36. Jian, J.; Steele, M.K.; Day, S.D.; Quinn Thomas, R.; Hodges, S.C. Measurement strategies to account for soil respiration temporal heterogeneity across diverse regions. Soil Biol. Biochem. 2018, 125, 167-177. [CrossRef]

37. Volpi, I.; Laville, P.; Bonari, E.; Nassi o Di Nasso, N.; Bosco, S. Nitrous oxide mitigation potential of reduced tillage and $\mathrm{N}$ input in durum wheat in the Mediterranean. Nutr. Cycl. Agroecosyst. 2018, 111, 189-201. [CrossRef]

38. Davidson, E.A.; Belk, E.; Boone, R.D. Soil water content and temperature as independent or confounded factors controlling soil respiration in a temperate mixed hardwood forest. Glob. Chang. Biol. 1998, 4, 217-227. [CrossRef]

39. Soussana, J.; Loiseau, P.; Vuichard, N.; Ceschia, E.; Balesdent, J.; Chevallier, T.; Arrouays, D. Carbon cycling and sequestration opportunities in temperate grasslands. Soil Use Manag. 2004, 20, 219-230. [CrossRef]

40. Balogh, J.; Papp, M.; Pintér, K.; Fóti, S.; Posta, K.; Eugster, W.; Nagy, Z. Autotrophic component of soil respiration is repressed by drought more than the heterotrophic one in dry grasslands. Biogeosciences 2016, 13, 5171-5182. [CrossRef]

41. Francioni, M.; Lai, R.; D’Ottavio, P.; Trozzo, L.; Kishimoto-Mo, A.W.; Budimir, K.; Baldoni, N.; Toderi, M. Soil respiration dynamics in forage-based and cereal-based cropping systems in central Italy. Sci. Agric. 2020, 77, 1-10. [CrossRef]

42. Liu, W.; Zhang, Z.; Wan, S. Predominant role of water in regulating soil and microbial respiration and their responses to climate change in a semiarid grassland. Glob. Chang. Biol. 2009, 15, 184-195. [CrossRef]

(C) 2019 by the authors. Licensee MDPI, Basel, Switzerland. This article is an open access article distributed under the terms and conditions of the Creative Commons Attribution (CC BY) license (http://creativecommons.org/licenses/by/4.0/). 